\title{
ASSESSMENT OF PERFORMANCE FOR ELASTOMERIC BEARINGS USED ON BRIDGES AND VIADUCTS
}

\author{
POPA Sorin Adrian \\ Ph.D. studet, Institute of Solid Mechanics, Romanian Academy, Bucharest, Romania; \\ Scientific Reasercher, Research Institute for Construction Equipment and Technology - ICECON S.A., \\ Bucharest, Romania; e-mail: sorin.popa@icecon.ro
}

\begin{abstract}
The in service safety and reliability assurance of bridges and viaducts is determined by the choice of materials and products suitable for the design bearing solution of that construction structure. The paper proposes an operational solution for the performance characteristics assessment and verification of elastomeric bearings, which will be the basis for the consistent and coherent application of the requirements established by technical and legal regulations in the construction domain.
\end{abstract}

Key words: structural bearings, performance assessment, product certification.

\section{Introduction}

The assessment of the capacity in the use for the elastomeric devices according to the specific requirements of a particular project / particular solution of bearing the superstructures for bridges and viaducts, is one of the basic steps for ensuring the safety and durability according to the provisions of Regulation (EU) no. 305/2011 on the marketing of construction products.
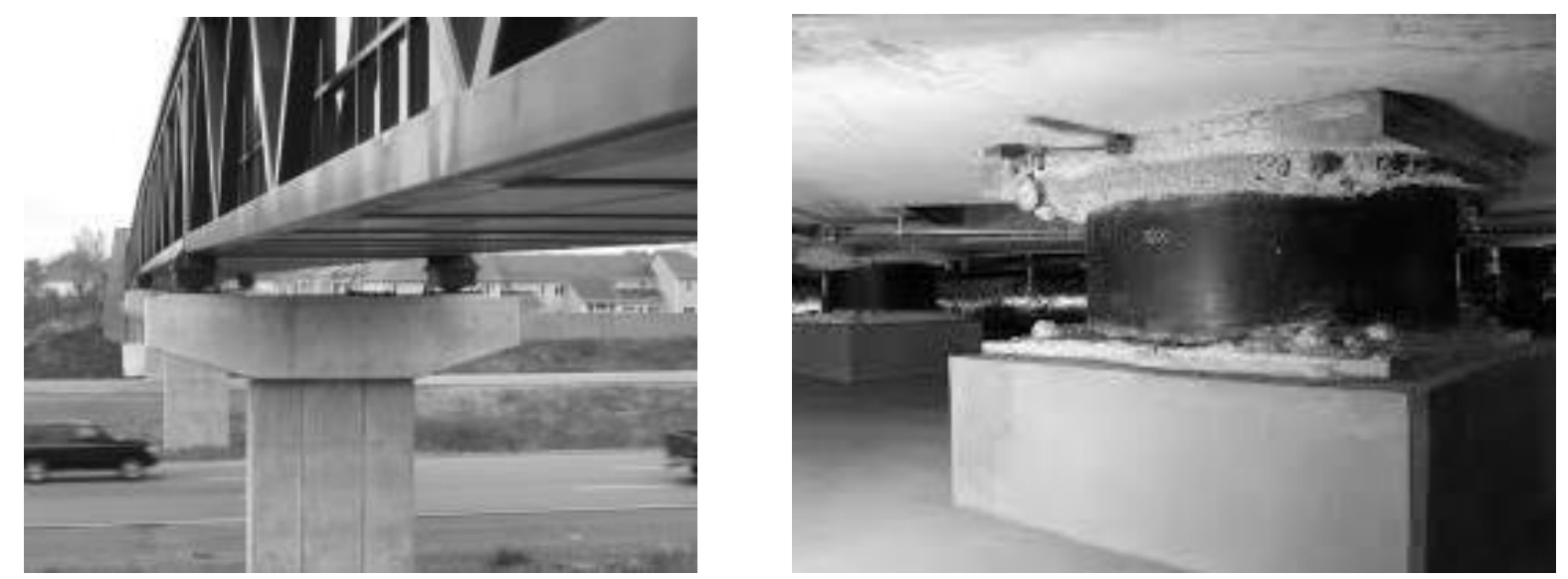

Figure 1: Example for intended use of elastomeric bearings

The technical capacity of the elastomeric bearing devices is assessed according to the essential characteristics defined in Annex ZA, table ZA.1 a $\div$ c of EN 1337-3 relative to the baseline / performance level required by the functional requirements defined by the construction structure's designer.

The appraisement of product performance (fulfilling the mandated requirements) is made directly by examining the results obtained by experimental tests, including checks by calculation for the designed functional requirements compared to the minimum admissible level / performance class for the intended conditions of use.

This article proposes an operational solution for analysing the performance characteristics of the elastomeric bearings, which forms the basis for the homogenous and consistent of the criteria and requirements specified by the technical regulations and the legal standards applicable in construction. 
ACTA UIVERSITATIS CIBINIENSIS - TECHNICAL SERIES

Vol. LXIX 2017

\section{Combined method for performance assessment}

\subsection{General conditions}

The demonstration of the specific technical capacities of the elastomeric bearings with / without additional devices used in bridge structures or in any other structure with comparable support conditions, is done according to the methods defined in EN 1337-3 by verifying the fulfilment of the designed constructive and functional requirements, of the performance characteristics expressed by value / level or class and of the technical specifications for the constituent materials.

Annex ZA3 / EN 15129 defines 3 methods of declaring the performance associated to the elastomeric bearings or the information accompanying the $\mathrm{CE}$ marking, applicable to the case, as follows:

- method 1: declaring values / level or class of performance for the essential characteristics defined in the reference document (EN 1337-3, Annex ZA), resulting from the experimental tests carried out according to the specific requirements for the use;

- method 2: declaring constituent materials properties that are relevant to the essential requirements (mechanical resistance and stability, durability, etc.); it is applicable to the verification of the design requirements and the definition of the calculation performance of a product;

- method 3: declaration of compliance with the calculation / design data specifications; it applies to the products manufactured according to the details of calculation prepared by the structure's designer or if the manufacturer has produced a structural component, according to the customer's requirements.

Given the wide range of type-sizes and functional requirements specific to the conditions of use (different for projects / specific work) the assessment of the bearings performance must be made for the "product type" defined according to each product family / categories (see section 8.3 and table 6 / EN 1337-3) under the conditions specified by the manufacturer in the product technical specification (level of external requests for the working environment, functional requirements to the service limit and the check items during the service) in accordance with the specifications of Annex E / EN 1337-3.

Generally, the functional performance appropriate for each constructive type-size of the bearings are set by calculations (design) based on the results obtained by experimental tests on type bearings (specimens). Upon the beneficiary's request, in particular for the projects / works where the requirements on individual bearings are critical (failures lead to exceeding the service limit state or the ultimate limit state) there shall be determined / experimentally verified the actual performance of that product type.

Starting from the fact that the EN 1337-3 standard does not specify how the results of the tests made on type specimens can be transferred on the finished products constructively and functionally similar, and considering the need to define a method for establishing and validating the limit functional requirements for a new product (prototype), it is hereunder presented an operational method for analysing the performance characteristics of the elastomeric bearings.

It is defined as a new product, and it is necessary to determine the specific performance, a bearing devices that meets the following conditions (assimilated in accordance with section 8.2.4 / EN 15129):

- different elastomer composition (elastomer material composition change);

- change form factor by minimum $10 \%$ compared to the already tested product;

- increase in exterior dimensions of the bearing device / reinforcement plates by more than $10 \%$;

- reduction in exterior dimensions of the bearing device plan/ reinforcement plates by more than $50 \%$;

- different production conditions (curing) - modification of manufacturing (technology) method:

- change of stiffness at compression and the conventional elasticity mode $(\mathrm{Gg})$ due to changes in the product's constructive solution and composition;

- change in conditions / domain of use: change of the min / max service temperature of the device

$\left(\mathrm{T}_{\mathrm{L}}>-3^{\circ} \mathrm{C} ; \mathrm{T}_{\mathrm{U}}>+5^{\circ} \mathrm{C}\right)$; increase of the specific shear deformation ( $\left.\varepsilon q\right)$, and of the shear 
solicitation $\left(\mathrm{F}_{\mathrm{xy}}\right)$; increase of compression load $\left(\mathrm{F}_{\mathrm{z}}\right)$ by more than $30 \%$ and the decrease of the minimum compression load $\left(\mathrm{F}_{z, \min }\right)$ by more than $10 \%$.

2.2 Stages of the process for validation of the elastomeric bearing devices performance.

(1) Determination/ identification of the physico-mechanical properties relevant to the constituent materials:

- elastomer: recipe specification (base polymer, dosing precision); shear module (G) - ISO 1827; tensile resistance (TS) and minimum elongation at break (Eb) - ISO 37; tear resistance (Ts) - ISO 341; residual deformation after compression - ISO 815; aging influence on mechanical characteristics:, tensile resistance and elongation at break - ISO 188; resistance to ozone (only for chloroprene rubber - CR) - ISO 1431-1;

- steel: steel brand; elongation at break (A); flow limit ( fy ) - EN 10025;

- PTFE: density - ISO 1183; traction resistance and elongation at break - ISO 527 -1.3; hardness EN ISO 2039-1; compression resistance - EN1337-2; PTFE surface friction coefficient - contact area- EN1337-2;

- adhesive: type (composition), concentration; steel-elastomer grip resistance - EN1337-2.

(2) Identification of constructive solution and verification of the execution conditions (sizes, geometry):

- geometric shape, configuration constructive and characteristic dimensions;

- calculation of the shape factor $(\mathrm{S})$;

- geometric conditions and execution tolerances.

(3) Define the conditions of use (work environment):

- minimum service temperature $\left(\mathrm{T}_{\mathrm{L}}\right)$ / maximum $\left(\mathrm{T}_{\mathrm{U}}\right)$ of the device; degree of exposure (medium duration) at low temperatures - ISO 6446 (section 4.3.2);

- environment aggressiveness (hazardous substances / anti-corrosion protection) - EN 1337-9;

- set-up conditions (characteristics of support material; anchorage system).

(4) Test - shear stress (Annex F, Annex G / EN 1337-3):

- determination of the conventional elasticity module $(\mathrm{Gg})$ for the bearing;

- establish the shear resistance $\left(\mathrm{R}_{\mathrm{xy}}\right)$ for the specific shear deformation $\varepsilon_{\mathrm{q}, \mathrm{d}}=1$, considering a safety coefficient depending on the importance of the construction and the verification of the maximum deformation $\left(\mathrm{v}_{\mathrm{xy}}\right)$;

- verification of the shear resistance at the steel-elastomer interface.

(5) Calculation - determining the limit functional conditions for the load and rotation capacity:

- calculation of the maximum vertical load (compression stress, $F_{z}$ );

- assessment of reduced plan area due to the shear stress $\left(\mathrm{A}_{\mathrm{r}}\right)$ and calculation of the value of specific compression deformation $\left(\varepsilon_{c, d}\right)$;

- calculation of establishment of size of total vertical deformation due to compression $\left(\mathrm{V}_{\mathrm{C}}\right)$ and estimation based on geometric conditions of the maximum value of the rotation angles $\left(\alpha_{\mathrm{a}, \mathrm{d}}, \alpha_{\mathrm{b}, \mathrm{d}}\right)$;

- calculation of the deformation value specific to rotation $\left(\varepsilon_{\alpha, \mathrm{d}}\right)$ and verification of the design request (section 5.3.3/ EN 1337-3) for the limit function state: $\varepsilon_{\mathrm{t}, \mathrm{d}}=\mathrm{K}_{\mathrm{L}} \cdot\left(\varepsilon_{\mathrm{c}, \mathrm{d}}+\varepsilon_{\mathrm{q}, \mathrm{d}}+\varepsilon_{\alpha, \mathrm{d}}\right) \leq \varepsilon_{u, d}$; - if the requirement of limiting the total maximum specific deformation, corresponding to the last limit state is not met, the functional conditions imposed upon the bearing are reconsidered and the calculation shall be remade.

(6) Test - compression stress (Annex H, Annex I / EN 1337-3):

- verification of stiffness to compression $\left(\mathrm{C}_{\mathrm{c}}\right)$, experimental determination of the secant compression mode $\left(\mathrm{E}_{\mathrm{cs}}\right)$ and recording the maximum compression deformation obtained experimentally $\left(\mathrm{V}_{\mathrm{C}}\right)$

- assessment of the repeated resistance to compression based on the secant compression module determined after dynamic fatigue $\left(\mathrm{E}_{\mathrm{cs}, \text { obs }}\right)$ and by verification regarding the occurrence of the surface defects due to manufacturing conditions;

- determination of actual value of the specific compression deformation $\left(\varepsilon_{\mathrm{c}}\right)$. 
ACTA UIVERSITATIS CIBINIENSIS - TECHNICAL SERIES

Vol. LXIX 2017

(7) Test - solicitation at rotation (Annex K/EN 1337-3):

- estimation of maximum value of the angles of rotation $\left(\alpha_{a}, \alpha_{b}\right)$ based on the experimentally determined deformation to compression; calculation of specific deformation due to rotation $\left(\varepsilon_{\alpha}\right)$;

- determination of maximum admitted value of the rotation angle $\left(\alpha_{R} \equiv \alpha_{b}\right)$ corresponding to that experimentally determined comeback moment (Me) and setting the permissible values for the angles of rotation.

(8) Calculation - verification of design requirements (validation of functional features):

- calculation of specific deformations due to external stress $\left(\varepsilon_{q}\right.$ - shearing; $\varepsilon_{c}$ - compression; $\varepsilon_{\alpha}$ rotation) and verification of the condition of limiting the maximum total deformation;

- verification by calculation of the requirements for resistance and stability, limitation of rotation and the anti-slip condition as appropriate (section 5.2 and section 5.3 / EN 1337-3).

\section{The results}

In order to assess the functional capacity of the bearings according to the intended domain of use, the experimental tests must be conducted under the conditions declared by the manufacturer and the calculation verification elements shall consider the actual characteristics of the product. The following table summarizes all the necessary elements to choose the bearings in accordance with the specific requirements of the project / construction work. There are specified the verification methods and the acceptance criteria for each relevant performance parameter.

Table 1: Assesment requirements

\begin{tabular}{|c|c|c|c|c|c|}
\hline No. & $\begin{array}{c}\text { Require- } \\
\text { ment }\end{array}$ & Performance parameter & $\begin{array}{c}\text { Verification } \\
\text { condition }\end{array}$ & $\begin{array}{l}\text { Acceptance criterion; Reference; } \\
\text { Value / Level / Performance class }\end{array}$ & $\begin{array}{l}\text { Test/check } \\
\text { method }\end{array}$ \\
\hline 0 & 1 & 2 & 3 & 4 & 5 \\
\hline 1.1 & \multirow{7}{*}{ 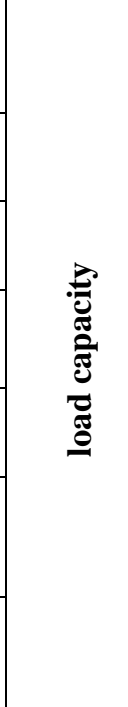 } & $\begin{array}{l}\text { conventional elasticity } \\
\text { module (shear), } \mathrm{G}_{\mathrm{g}}\end{array}$ & $\begin{array}{l}\text { pts. } 4.3 .1 / \\
\text { EN } 1337-3\end{array}$ & $\begin{array}{c}\mathrm{G}_{\mathrm{g}}=0,9 \pm 0,15 \mathrm{MPa}\left(\mathrm{T}_{\mathrm{N}}=23^{\circ} \mathrm{C}\right) \\
\mathrm{G}_{\mathrm{g}, \mathrm{TL}} \leq 3 \mathrm{G}_{\mathrm{g}}\left(\mathrm{T}_{\mathrm{L}} \in-25^{\circ} \mathrm{C} ;-40^{\circ} \mathrm{C}\right) \\
\mathrm{G}_{\mathrm{g}, \mathrm{imb}} \leq 3 \mathrm{G}_{\mathrm{g}}\left(3 \text { days at } 70^{\circ} \mathrm{C}\right)\end{array}$ & $\begin{array}{l}\text { test - annex F/ } \\
\text { EN 1337-3 }\end{array}$ \\
\hline 1.2 & & $\begin{array}{l}\text { resistance to shear steel- } \\
\text { elastomer grip }\end{array}$ & $\begin{array}{l}\text { pts. } 4.3 .2 / \\
\text { EN } 1337-3\end{array}$ & $\begin{array}{l}\text { without grip deterioration / surface flaws; } \\
\text { uniform increase force-deformation curve slope }\end{array}$ & $\begin{array}{l}\text { test - annex G / } \\
\text { EN } 1337-3\end{array}$ \\
\hline 1.3 & & stiffness to compression, $\mathrm{C}_{\mathrm{c}}$ & $\begin{array}{l}\text { pts. } 4.3 .3 / \\
\text { EN } 1337-3\end{array}$ & $\begin{array}{l}\text { technical specification / execution project } \\
\qquad\left(\mathrm{F}_{\mathrm{z}, \mathrm{d}} ; \varepsilon_{\mathrm{c}} ; \mathrm{C}_{\mathrm{c}} ; \mathrm{E}_{\mathrm{cs}}\right)\end{array}$ & $\begin{array}{l}\text { test - annex H / } \\
\text { EN } 1337-3\end{array}$ \\
\hline 1.4 & & $\begin{array}{l}\text { repeated resistance to } \\
\text { compression, } E_{\mathrm{cs}, \mathrm{obs}}\end{array}$ & $\begin{array}{l}\text { pts. } 4.3 .4 / \\
\text { EN } 1337-3\end{array}$ & $\begin{array}{l}\qquad \mathrm{E}_{\mathrm{cs}, \mathrm{obs}} \leq \mathrm{E}_{\mathrm{cs}}(1+12 \%) \\
\text { without surface flaws/ device deterioration }\end{array}$ & $\begin{array}{l}\text { test - annex I/ } \\
\text { EN 1337-3 }\end{array}$ \\
\hline 1.5 & & $\begin{array}{l}\text { mechanic resistance } \\
\text { reinforcement plate }\end{array}$ & $\begin{array}{l}\text { pts. } 4.4 .3 / \\
\text { EN } 1337-3\end{array}$ & $\begin{array}{l}\text { thickness of internal reinforcements }\left(t_{s}\right) / \text { exterior } \\
\left(t_{t}\right) ; t_{s} \geq 2 \mathrm{~mm} ; t_{s} \text {, efectiv }>t_{s} \text {, calculation; } t_{t} \geq 15 \mathrm{~mm} \text {. }\end{array}$ & $\begin{array}{l}\text { calculation- pts. } \\
\text { 5.3.3.5/ EN 1337-3 }\end{array}$ \\
\hline 1.6 & & $\begin{array}{l}\text { resistance and stability } \\
\text { (SLU) }\end{array}$ & $\begin{array}{l}\text { pts.5.2 / } \\
\text { EN } 1337-3\end{array}$ & $\begin{array}{l}\text { condition: } \mathrm{S}_{\mathrm{d}}<\mathrm{R}_{\mathrm{d}} \text { ( buckling stability; anti- } \\
\text { gliding condition }- \text { not anchored device case) }\end{array}$ & $\begin{array}{c}\text { calculation- pts. } \\
5.3 ; 5.4 ; 5.5 / \mathrm{EN} \\
1337-3\end{array}$ \\
\hline 1.7 & & $\begin{array}{l}\text { specific maximum } \\
\text { deformation, } \varepsilon_{\mathrm{u}, \mathrm{k}} \text { for SLU }\end{array}$ & $\begin{array}{l}\text { pts.5.3.3 / } \\
\text { EN } 1337-3\end{array}$ & $\begin{array}{c}\varepsilon_{\mathrm{t}, \mathrm{d}}=\mathrm{K}_{\mathrm{L}} \cdot\left(\varepsilon_{\mathrm{c}, \mathrm{d}}+\varepsilon_{\mathrm{q}, \mathrm{d}}+\varepsilon_{\alpha, \mathrm{d}}\right) \leq \varepsilon_{u, d} \\
\text { technical specification / execution project }\end{array}$ & $\begin{array}{l}\text { calculation- pts. } \\
\text { 5.3.3 / EN 1337-3 }\end{array}$ \\
\hline 2.1 & \multirow{3}{*}{ 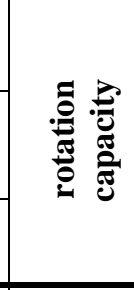 } & rotation angles $\left(\alpha_{a}, \alpha_{b}\right)$ & $\begin{array}{c}\text { pts. } 5.3 ; 5.4 ; \\
5.5 / \text { EN } 1337-3\end{array}$ & $\propto_{\mathrm{b}}=\frac{\mathrm{t}_{\mathrm{e}}^{3} \cdot \mathrm{K}_{\mathrm{s}} \cdot \mathrm{M}_{\mathrm{e}}}{\mathrm{G}_{\mathrm{g}} \cdot \mathrm{a}^{5} \cdot \mathrm{b}} ; \propto_{\mathrm{a}}=\operatorname{arctg}\left(\operatorname{tg} \alpha_{\mathrm{b}} \cdot \mathrm{a} / \mathrm{b}\right)$ & $\begin{array}{l}\text { calculation- pts. } \\
\text { 5.3.3.6 / EN 1337-3 }\end{array}$ \\
\hline 2.2 & & $\begin{array}{l}\text { specific deformation due to } \\
\text { rotation }\left(\varepsilon_{\alpha}\right)\end{array}$ & $\begin{array}{c}\text { pts. } 5.3 ; 5.4 ; \\
5.5 / \text { EN } 1337-3\end{array} \mid$ & $\varepsilon_{\alpha}=\frac{\left(\left(a^{\prime}\right)^{2} \cdot \alpha_{a}+\left(b^{\prime}\right)^{2} \cdot \alpha_{b}\right) \cdot t_{i}}{2 \sum t_{i}^{3}}$ & $\begin{array}{l}\text { calculation- pts. } \\
\text { 5.3.3.4/ EN 1337-3 }\end{array}$ \\
\hline 2.3 & & $\begin{array}{l}\text { resistance to rotation }(\mathrm{M}) / \\
\text { come back moment }(\mathrm{Me})\end{array}$ & $\begin{array}{l}\text { pts. } 4.3 .5 / \\
\text { EN } 1337-3\end{array}$ & $\mathrm{M}=\mathrm{G} \cdot \frac{\alpha \cdot\left(\mathrm{a}^{\prime}\right)^{5} \cdot\left(\mathrm{b}^{\prime}\right)}{\mathrm{n} \cdot t_{i}^{3} \cdot K_{\mathrm{c}}}$ & $\begin{array}{l}\text { test - annex K/ } \\
\text { EN } 1337-3\end{array}$ \\
\hline 3.1 & \multirow{2}{*}{ 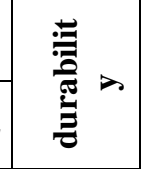 } & $\begin{array}{l}\text { resistance to ozone } \\
\text { ( elastomeric bearing ) }\end{array}$ & $\begin{array}{l}\text { pts. } 4.3 .6 / \\
\text { EN } 1337-3\end{array}$ & without surface flaws/ device deterioration & $\begin{array}{l}\text { test - annex L / } \\
\text { EN 1337-3 }\end{array}$ \\
\hline 3.2 & & $\begin{array}{l}\text { resistance to shear grip } \\
\text { PTFE - elastomer }\end{array}$ & $\begin{array}{l}\text { pts. } 4.3 .7 / \\
\text { EN } 1337-3\end{array}$ & $\begin{array}{l}\text { without grip deterioration; } \\
\text { uniform increase force-deformation curve slope }\end{array}$ & $\begin{array}{l}\text { test - annex M / } \\
\text { EN } 1337-3\end{array}$ \\
\hline
\end{tabular}


ACTA UIVERSITATIS CIBINIENSIS - TECHNICAL SERIES

DOI: 10.1515/aucts-2017-0006

Vol. LXIX 2017

\begin{tabular}{|c|c|c|c|c|c|}
\hline 0 & 1 & 2 & 3 & 4 & 5 \\
\hline 3.3 & & $\begin{array}{l}\text { physical and mechanic } \\
\text { properties of elastomer }\end{array}$ & $\begin{array}{l}\text { pts. } 4.4 .2 / \\
\text { EN } 1337-3\end{array}$ & $\begin{array}{l}\text { according to the requirements in table 1/ } \\
\text { EN 1337-3 }\end{array}$ & $\begin{array}{l}\text { tests }- \text { table } 8 / \\
\text { EN } 1337-3\end{array}$ \\
\hline 3.4 & & $\begin{array}{l}\text { features/conditions for the } \\
\text { environment of use }\end{array}$ & $\begin{array}{l}\text { pts. } 4.3 .2 / \\
\text { ISO } 6446\end{array}$ & $\begin{array}{c}\text { technical specification / execution project; }\left(\mathrm{T}_{\mathrm{L}}\right. \\
\mathrm{T}_{\mathrm{U}} ; \text { degree of exposure to } \mathrm{T}_{\mathrm{L}} ; \text { aggressive } \\
\text { environment; set-up) }\end{array}$ & data review \\
\hline 3.5 & & $\begin{array}{l}\text { gliding area constructive } \\
\text { solution (PTFE) }\end{array}$ & $\begin{array}{l}\text { pts. } 4.4 .4 / \\
\text { EN } 1337-3\end{array}$ & $\begin{array}{l}\text { geometrical and dimensional characteristics } \\
\text { specified in section 5.2.3; 6.2;7.1.1/ EN 1337-2 }\end{array}$ & $\begin{array}{l}\text { verifications - table } \\
12 \text { / EN 1337-2 }\end{array}$ \\
\hline 3.6 & & $\begin{array}{l}\text { PTFE physical and mechanic } \\
\text { properties; (friction coefficient) }\end{array}$ & $\begin{array}{l}\text { pts. } 5.6 / \\
\text { EN } 1337-3\end{array}$ & $\begin{array}{l}\text { according to the requirements in table } 5 \text { and } \\
\text { table } 10 / \text { EN } 1337-2\end{array}$ & $\begin{array}{l}\text { tests - pts. } 5.2 / \\
\text { EN } 1337-2\end{array}$ \\
\hline 3.7 & & $\begin{array}{l}\text { resistance to corrosion for } \\
\quad \text { exposed metal areas }\end{array}$ & $\begin{array}{l}\text { pts. 4.1.1.1/ } \\
\text { EN 1337-9 }\end{array}$ & $\begin{array}{l}\text { according to the requirements in table 1/ } \\
\text { EN 1337-9 }\end{array}$ & $\begin{array}{l}\text { tests }- \text { table } 1 / \\
\text { EN } 1337-9\end{array}$ \\
\hline 4.1 & \multirow{4}{*}{ 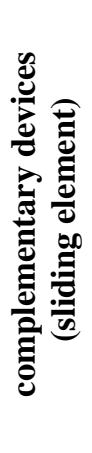 } & $\begin{array}{l}\text { constructive and dimensional } \\
\text { characteristics }\end{array}$ & $\begin{array}{l}\text { pts. } 6.5 ; 7 / \\
\text { EN } 1337-2\end{array}$ & $\begin{array}{l}\text { technical specification } \\
\text { (dimensions in table } 13 \text { an } 14 \text { / EN 1337-2) }\end{array}$ & data review \\
\hline 4.2 & & $\begin{array}{c}\text { load capacity for support plate } \\
\text { (sliding element) }\end{array}$ & $\begin{array}{c}\text { pts. } 6.8,6.9 ; \\
5.4 ; 5.6 / \\
\text { EN } 1337-2 \\
\end{array}$ & $\begin{array}{l}\text { condition: } \mathrm{S}_{\mathrm{d}}<\mathrm{R}_{\mathrm{d}} \text { ( thickness, rigidity, physical } \\
\text { and mechanic properties of the material); } \\
\text { technical specification. }\end{array}$ & $\begin{array}{c}\text { verifications- } \\
\text { annex A, C; table } \\
11 / \mathrm{EN} 1337-2 \\
\end{array}$ \\
\hline 4.3 & & $\begin{array}{l}\text { fraction coefficient (support } \\
\text { plate- bearing) }\end{array}$ & $\begin{array}{l}\text { pts.4.1.1; } 6.7 / \\
\text { EN } 1337-2\end{array}$ & $\begin{array}{l}\text { according to the requirements in table } 1 \text { and } \\
\left.\text { table } 11 \text { / EN } 1337-2 \text { (values: } \mu_{\mathrm{s}, 1} ; \mu_{\mathrm{din}, 1} ; \mu_{\max }\right)\end{array}$ & $\begin{array}{l}\text { test - annex B, D/ } \\
\text { EN } 1337-2\end{array}$ \\
\hline 4.4 & & $\begin{array}{l}\text { gliding element durability } \\
\text { (support plate) }\end{array}$ & $\begin{array}{l}\text { pts.7.3; } 7.4 ; \\
7.1 / \text { EN } 1337-2 \\
\text { pts.4.1.1.1 / } \\
\text { EN } 1337-9 \\
\end{array}$ & $\begin{array}{l}\text { physical and mechanical properties of the } \\
\text { lubricant; protection to contamination system - } \\
\text { EN 1337-2; according to the requirements in } \\
\text { table 1/ EN 1337-9. }\end{array}$ & $\begin{array}{l}\text { test - annex G, H / } \\
\text { EN 1337-2; } \\
\text { tests - table 1/ } \\
\text { EN 1337-9 }\end{array}$ \\
\hline
\end{tabular}

Below it is presented the test bench and some experimental results obtained in the ICECON TEST - Bucharest laboratory.
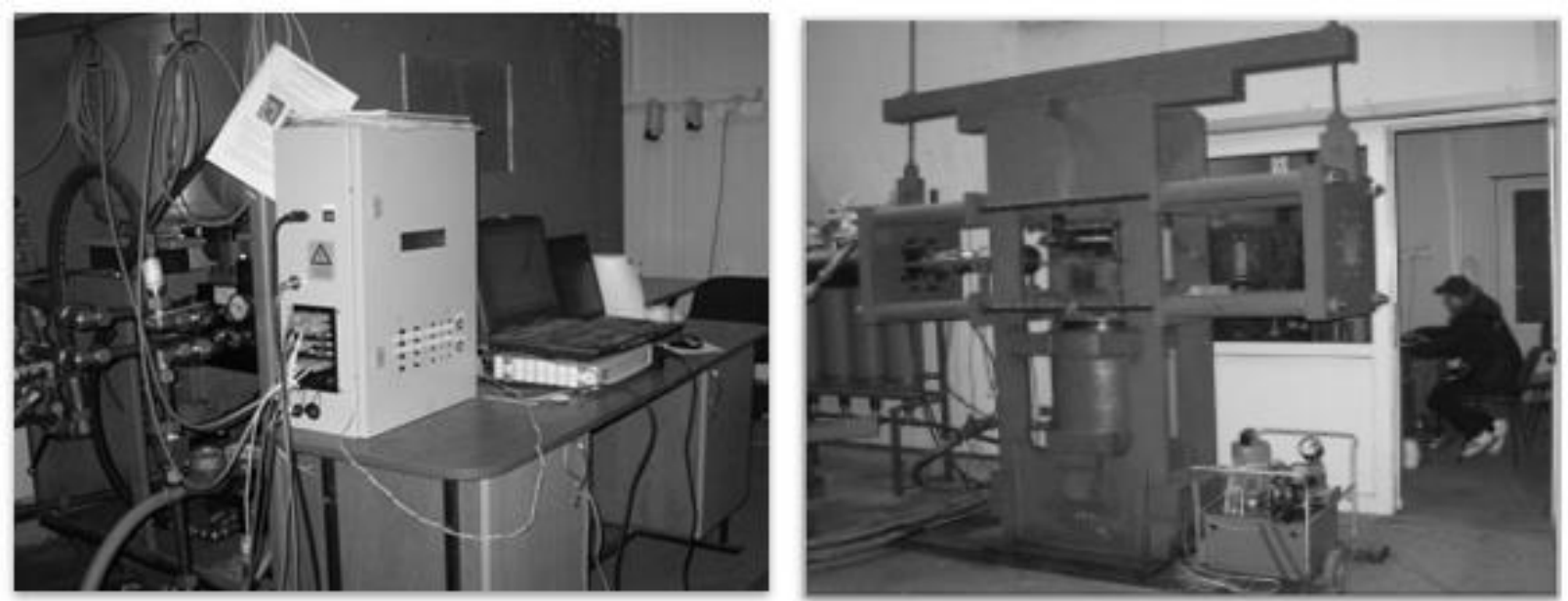

Figure 2: Test stand - ICECON TEST Laboratory: a) control and monitoring system test parameters; b) test equipment (hydraulic press with two independent lines of action). 

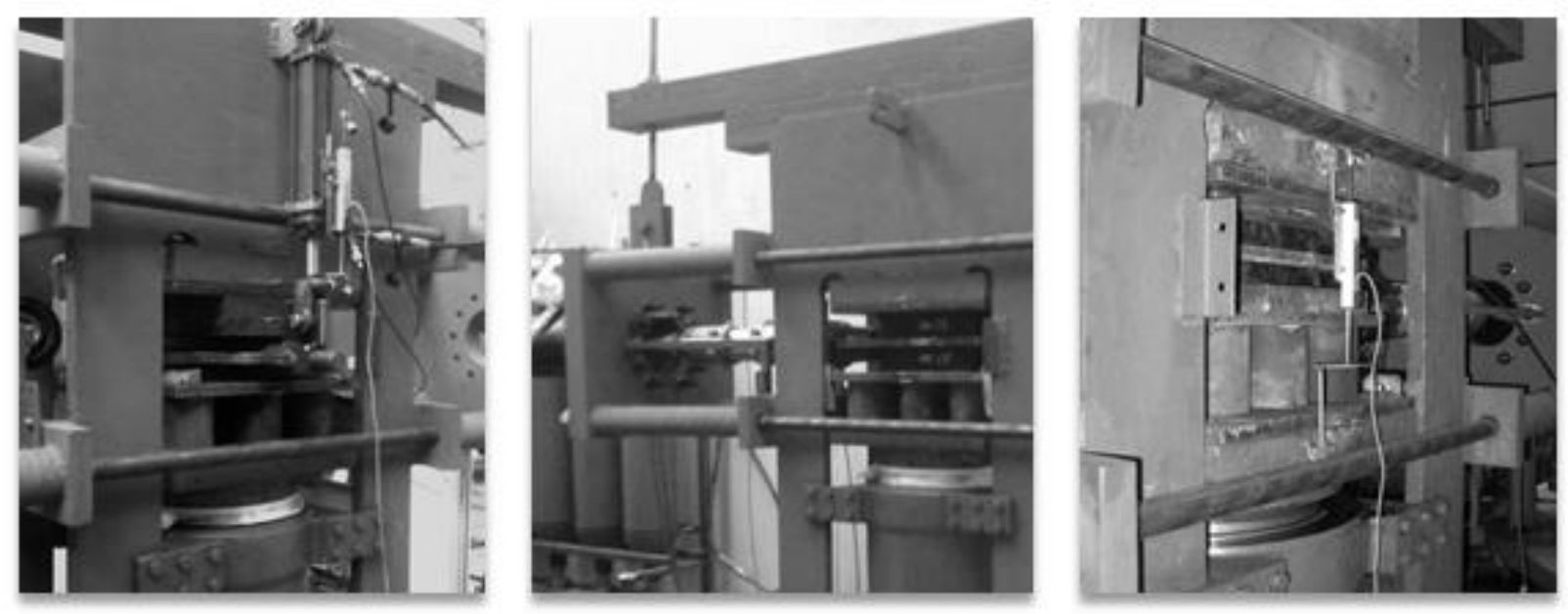

Figure 3: Performance testing for the elastomeric structural bearings: a) rotation capability test (Annex K/ EN 1337-3); b) shear test (Annex F/ EN 1337-3) c) compression test (Annex H/ EN 1337-3).
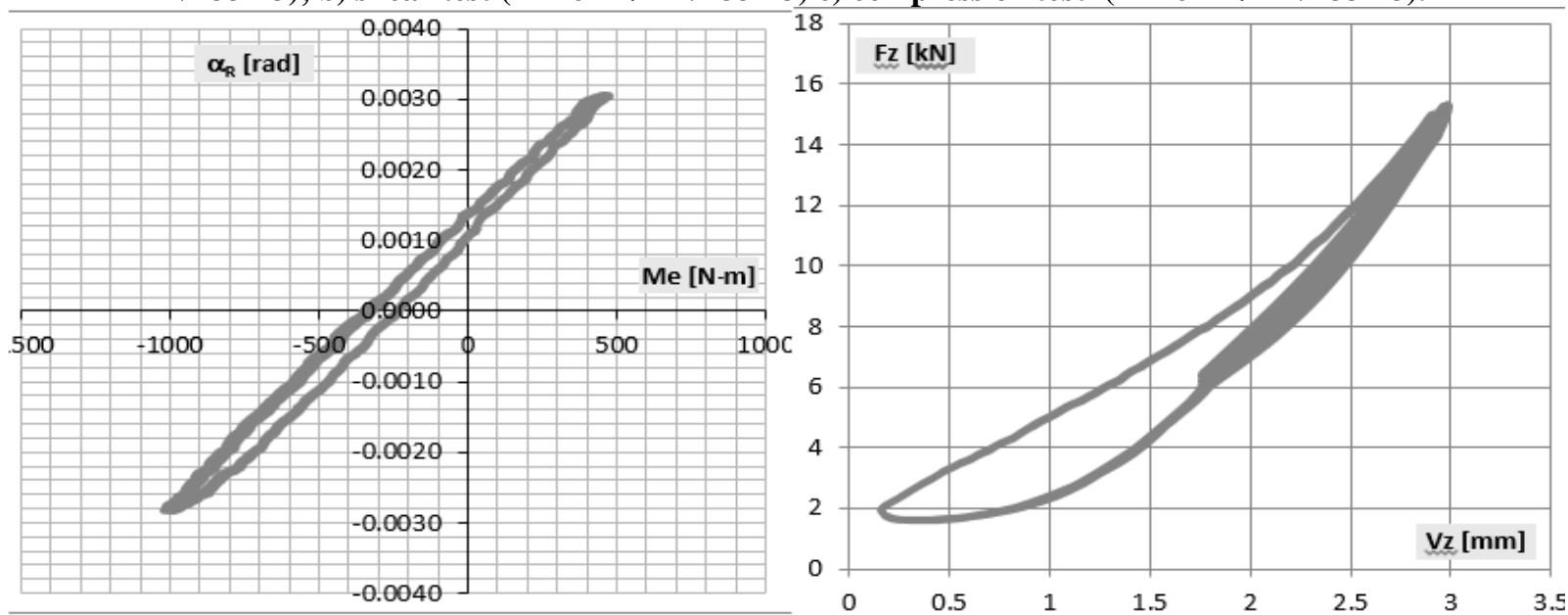

Figure 4: Experimental results: a) resistance to rotation ; b) Repeated compression resistance

\section{Conclusions}

The information accompanying the product (statement content / performance certificate) must enable the assessment of the aptitude of use for a particular project / base isolation work.

The EN 1337-3 standard does not require levels / classes of performance for the product's characteristics as the functional requirements and the specific conditions of use for a particular project / work may differ significantly. For this reason, the manufacturer must elaborate a technical specification of the product in which to define the minimum level of performance associated to its characteristics (measurable parameters) assured in compliance with intended use requirements.

The warranty granted by the manufacturer for the product performance (in service / in operation) is based on the inspection made by the qualified personnel with proven experience (third party inspection is recommended), in accordance with the legal regulations in force (see EN 1337-10). Also, the manufacturer is required to apply a manufacturing control system demonstrating that the product has been tested and met the defined criteria of acceptance.

The experimental results obtained after applying the method of analysis of the performance characteristics of the elastomers bearings proposed in this article will contribute to the achievement of a database to enable the definition of a mathematical model, based on which the behaviour of the constructively similar products shall be precisely assessed. 
ACTA UIVERSITATIS CIBINIENSIS - TECHNICAL SERIES

Vol. LXIX 2017

\section{References}

1. Polidor, Bratu., Analysis of elastic structures: behavior for static and dynamic actions, IMPULS Publishing House, Bucharest, (2011).

2. Polidor, Bratu., Mecanica sistemelor deformabile, IMPULS Publishing House, Bucharest, (2006).

3. Regulation (EU) No 305/09.03.2011 - Harmonised conditions for the marketing of construction products and repealing Council Directive 89/106/EEC, (2011).

4. Standard SR EN 1337-3:2005, Structural bearings - Part 3: Elastomeric bearings, Bucharest, (2005).

5. Standard SR EN 15129, Anti-seismic devices, Bucharest, (2010). 